\title{
Rural Tourism as a Transformative Service of Community Well-Being: A Systematic Literature Review
}

\author{
Shamim Ahmad Siddiqui ${ }^{1}$, Sanjai Parahoo ${ }^{1}$, Md Abu Nayeem Sadi², Munshi Naser Ibne Afzal2* \\ ${ }^{1}$ School of Business \& Quality Management, Hamdan Bin Mohammed Smart University, Dubai, P.O box- 71400, UAE \\ ${ }^{2}$ Department of Economics, Shahjalal University of Science and Technology, Sylhet 3114, Bangladesh
}

Corresponding Author Email: munshinaser-eco@sust.edu

https://doi.org/10.18280/ijsdp.160609

Received: 11 August 2021

Accepted: 10 October 2021

\section{Keywords:}

systematic review, bibliometric review, thematic analysis, rural tourism, transformative service, content analysis

\begin{abstract}
This study aims to look at the pattern and focus of rural tourism research over the last two decades. How much current research on rural tourism has centered on the position of rural tourism as a transformative service industry, in particular. A rigorous search is conducted in the current scientific literature databases, integrating narrative review and bibliometric research, to evaluate this correlation as well as to assess the effect of rural tourism growth on the various actors in the ecosystem (i.e., local population, local service providers, local authorities, tourists). It also includes a narrative study of clusters of topics under the headings of rural tourism and community well-being. We conducted a systematic thematic and material study of our chosen literature in addition to bibliometric analysis. Finally, a critical analysis of the methodologies used in the field of rural tourism is conducted. Since the connection between tourism growth and local TSR is still being researched, this study uses well-being (and other related terms) as an inclusion criterion for all types of tourism in rural areas. The report also aims to assess research progress on terms related to rural tourism, such as eco-tourism, nature tourism, adventure tourism, and community-based tourism, from 2010 to 2020 . Furthermore, the study examines the relationship between rural tourism and well-being before and after 2010. The choice of 2010 as the turning point reflects the fact that after 2010, the relation between TSR (or wellbeing) and rural tourism becomes more visible. By using title, citations, publication journal and year, author information, keywords (name, countries, and institutions analysis), and author information, this search provides us with an aesthetic nature of our research. This paper set an agenda for future research in the field. Future researchers will get a clear insight about literature gap in the field of tourism industry.
\end{abstract}

\section{INTRODUCTION}

There are many forms of tourism that can maintain sustainable tourism standards and practices [1-3]. However, every form of tourism, on its own, may not match the requirement of sustainable development and well-being of the tourist site community (Buryat State Agricultural Academy named after V. R. Philippov (BSAA)) [4]. Over the past few decades, there has been an increasing scholarly interest in the relationship between tourism and well-being across a wide range of disciplines such as psychology, economics, and health sciences [5]. The relations between tourism and happiness, subjective well-being (SWB), life satisfaction, quality of life (QOL) and wellbeing were explored in several studies [5-8]. With the advent of the Transformative Service Research (TSR) field, scholars are increasingly stressing the transformative role that micro- and macro-level services can play.

Community well-being is made up of multiple forms of capital and developing multiple ways in which tourism development contributes to, or detracts from, the different forms of capital available to destination communities [9]. This paper used Flora's (2004) community wellbeing framework where it is argued that community wellbeing is build up with various form capital including cultural (the stock of rituals), social (the stock of trust), human, political (access to decisionmakers), natural (stock of resources and assets provided to the community by natural systems and environments), financial (money available within and to the community).

Transformative Service Research (TSR) is defined as "the integration of consumer and service research that centers on creating uplifting changes and improvements in the wellbeing of consumer entities: individuals (consumers and employees), communities, and the ecosystem" [10]. It was recently launched as a direct outgrowth of the groundbreaking Transformative Consumer Research (TCR) movement [11, 12]. While TCR focuses on the health effects of consumer consumption, TSR emphasizes the role of service and service ecosystems in affecting individual and collective well-being [13]. The basic idea is that the only way to achieve sustainable benefit is by promoting collective well-being [14]. Importance of transformative service research has grown significantly across different branches of service sector such as in financial service and healthcare service $[15,16]$ and hospitality service [17]. For example, another study investigate the Albergo Diffuso model through the lens of TSR, and provide new research avenues for service scholars interested in individual and collective well-being in the tourism industry [18]. 
While the concept of TSR is attractive and somewhat novel, it must be recognized that the sustainability of rural tourism (and for that matter, tourism in general), which in its broader meaning, includes impact on the wellbeing of all stakeholders is not completely new. It would be, therefore, quite apposite to use the concept of wellbeing (and other concepts that relate to wellbeing as proxies for TSR) to explore how tourism and wellbeing research have gone hand in hand. For example, viewed from the perspective of the local community, the shrinking of the primary sector may be compensated by a tertiary sector activity like rural tourism. The latter has the potential to enhance economic development by providing employment and increasing income to the villagers [19]. Rural tourism offers benefits to stakeholders at multiple levels: individual service provider, collective community level, and even regional level. The rural community receives social benefits in terms of development of public services such as road infrastructure, education, health, and exposure to different cultures as well as economic benefits [14]. Economic benefits accrue in terms of increased income and employment opportunities for the local inhabitants. Furthermore, rural tourism may help in reversing the brain drain of village inhabitants who migrate to cities in search of better livelihood opportunities by motivating them to come back to the village $[20,21]$.

This research is an attempt to investigate the trend and foci of rural tourism research during the last two decades. In particular, how far the existing research on rural tourism has focused on the role of rural tourism as a transformative service industry. Since the correlation to tourism development with TSR in local area is still under-developed, this research deliberately uses well-being (and other related terms) as an inclusion criterion for all forms of tourism implemented in rural areas. The study also aims to review the research progress on rural tourism related terms such as eco-tourism, nature tourism, adventure tourism and community-based tourism for the period of 2010-2020. Furthermore, the research highlights the link between rural tourism and its relationship to wellbeing before and after 2010 . The choice of 2010 as the turning point reflects the fact that link between TSR (or wellbeing) and rural tourism gets under the spot light after 2010 . To analyze this link as well as to assess the impact of rural tourism development on the various actors in the ecosystem (i.e., local community, local service providers, local authorities, tourists) a robust search is carried out in the existing scientific literature databases using Systematic literature Review Method, and by incorporating narrative review and a bibliometric analysis. This search gives us an aesthetic nature of our study by applying title, citations, publication journal and year, author's information, keywords (name, countries and institutions analysis. Moreover, it addresses the narrative review of clusters of themes under rural tourism and community wellbeing. Besides bibliometric analysis, we have done a thorough thematic and content analysis of our selected literature. Besides, to set an agenda for future research in the area, a critical review of the methodologies used in the area of rural tourism is also carried out.

The paper is organized as follows. After this introduction section, the next section "Methods and data" details research methods and data. "Results" presents research results and "Research key points" discusses future research directions and raises policy recommendations, as well as research limitations. Finally, "Conclusions" draws research conclusions.

\section{METHODOLOGY}

\subsection{Methodology for Bibliometric analysis}

In the past ten years, only a few research works came out in the field of community-based tourism or rural tourism using bibliometric analysis. There are in fact only two main researches, one with tourism and the other with eco-tourism titles [22, 23]. So far, there has been no analysis using bibliometric system of rural tourism and well-being. In this paper, the first part of the research is mainly focused on bibliometric analysis, so that different publication characteristics related to rural tourism and well-being can be revealed, before and after the eco / community-oriented / adventure tourism (publications discussing tourism in rural areas which ensure the well-being of the local community). Basically, we have applied inclusion criteria based on the year that researchers first introduced transformative service research $[10,12]$. Transformative Services Research (TSR) definition was first conceptualized as an examination of the service-wellbeing relationship. Rural tourism is used here as a support resource for the local population to boost their wellbeing. Other characteristics apart from journal publication styles were study of keywords and names, organizations, countries, and citation patterns, along with research criteria, for research.

Bibliometrics can provide models for the evolution of science, technology, and scholarship [24-26]. The bibliometric study process has been expanded from repositories to other areas to guide and choose the pathways to follow for the next generation of scientific progress [27,28]. the benefit of time series bibliometric analysis is that identifies topics inside law, as well as knowledge-intensive study [29]. Here is a flowchart illustrating the bibliometric study of our project (Figure 1).

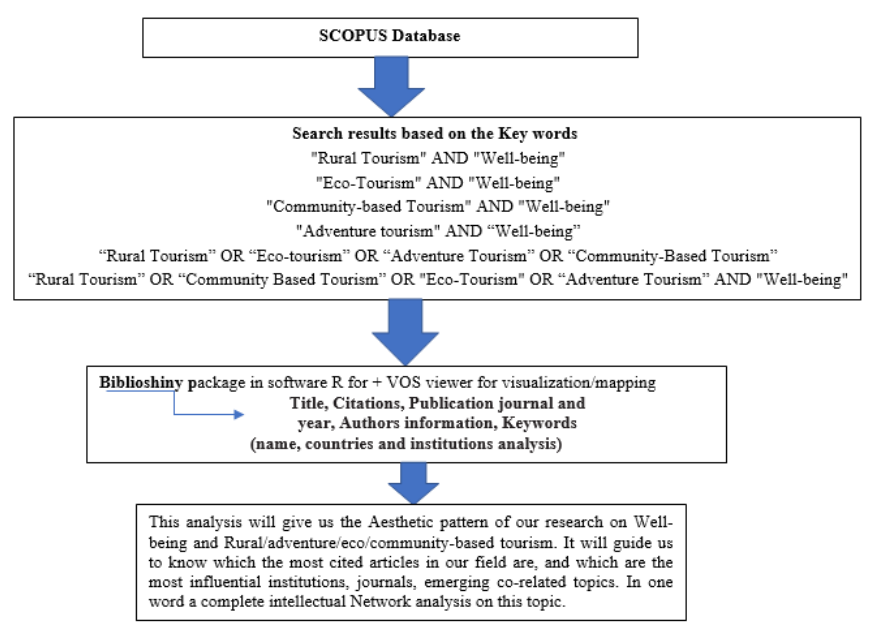

Figure 1. The flowchart of systematic bibliometric review

\section{DATA COLLECTION AND NETWORK ANALYSIS}

In principle, it is common knowledge that SCOPUS and Web of Science are two of the world's most prestigious and reliable databases [22]. However, in terms of the search criteria and its results, these two repositories fit very closely [23]. Typically, 1 to 2 per cent of total articles in both repositories may not suit the same keyword quest. These two repositories thus cover all written documentation and citation repositories in all science fields, and have become useful 
resources for bibliometric research [30, 31]. In our case, bibliometric data was obtained for study using SCOPUS database. Figure 2 shows the review flowchart and filters data containing rural tourism and wellbeing from keywords Level 1 filters. To avoid unnecessary publications, both manual screening and Biblioshiny applications were implemented at Level 2.

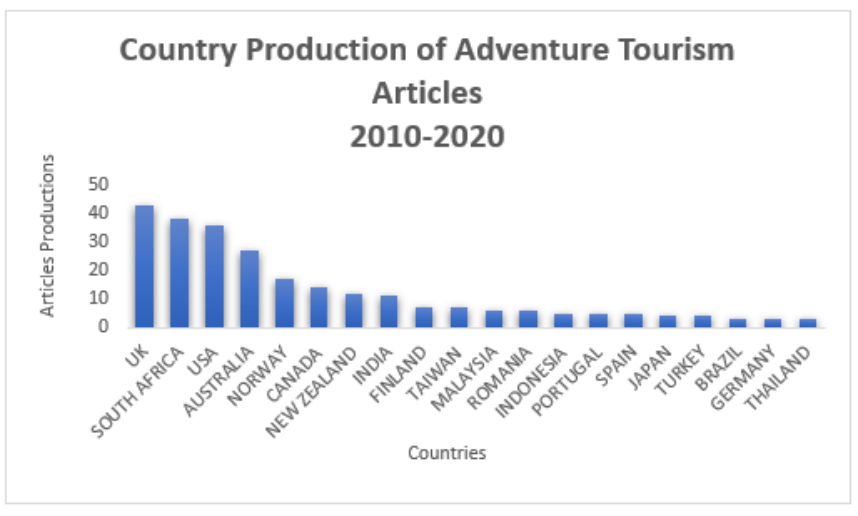

Figure 2. Country production as first author basis in Adventure Tourism articles publications 2010-2020

Keywords including Rural Tourism, Community Based Tourism, Adventure Tourism, Eco-tourism were used separately to search the related publications on SCOPUS during the period of 2010-2020. We are interested to see the impact of number of research relating Rural/Communitybase/Adventure/Eco-tourism - to well-being, before and after 2010 when first TSR term is used. Moreover, the search is also conducted on each title of rural tourism during 2010-2020 to find out the recent trend in local tourism research.

\section{RESULTS AND DISCUSSION}

\subsection{The performance of related publications}

The annual publications and average citations on Adventure Tourism (AT), Community-Based Tourism (CBT), EcoTourism (EcoT) and Rural tourism (RT) are presented in Table 1. It is clear that both annual publications and annual citations increased in Rural tourism related research, indicating the growing academic interest particularly in Rural tourism compared to other similar categories of local tourism research such as Adventure, Eco and Community-based tourism during 2010-2020 compared to 2000-2010. This also echoes the global trend on environmental protection, community involvement in rural areas. This may imply that, among four dominant keywords which account for local tourism research, researchers use Rural Tourism term more often in recent years which makes this term as an established term for local community-based tourism research. In addition, with increasing incomes, more people began to involve in tourism, particularly in those developing countries where rural areas are key for building adventure, community and eco-tourism infrastructure. By looking at the annual production of articles using 'Rural Tourism' as the key word from our Table 1, it is almost double than Eco-Tourism and triple than Community based tourism research during the year 2010-2020. However, in terms of total annual citation from table 01 , the numbers are close to each other in adventure (55), eco (60) and communitybased articles (75). Whilst, the number of citations in rural tourism (112) research is almost doubled meaning that academic recognition of the term rural tourism research in the field of local community-based tourism studies are emphasized.

Table 1. The performance of related publications 2010-2020

\begin{tabular}{ccccc}
\hline & $\begin{array}{c}\text { Adventure } \\
\text { Tourism }\end{array}$ & $\begin{array}{c}\text { Community- } \\
\text { Based } \\
\text { Tourism }\end{array}$ & $\begin{array}{c}\text { Eco- } \\
\text { tourism }\end{array}$ & $\begin{array}{c}\text { Rural } \\
\text { Tourism }\end{array}$ \\
\hline $\begin{array}{c}\text { Total } \\
\text { Publication } \\
\text { Total }\end{array}$ & 176 & 309 & 404 & 957 \\
Citations & 55 & 60 & 75 & 112 \\
\hline
\end{tabular}

The annual publications and average citations on Adventure Tourism (AT), Community-Based Tourism (CBT), EcoTourism (EcoT) and Rural tourism (RT) are presented in Table 1. It is clear that both annual publications and annual citations increased in Rural tourism related research, indicating the growing academic interest particularly in Rural tourism compared to other similar categories of local tourism research such as Adventure, Eco and Community-based tourism during 2010-2020 compared to 2000-2010. This also echoes the global trend on environmental protection, community involvement in rural areas. This may imply that, among four dominant keywords which account for local tourism research, researchers use Rural Tourism term more often in recent years which makes this term as an established term for local community-based tourism research. In addition, with increasing incomes, more people began to involve in tourism, particularly in those developing countries where rural areas are key for building adventure, community and eco-tourism infrastructure. By looking at the annual production of articles using 'Rural Tourism' as the key word from our Table 1, it is almost double than Eco-Tourism and triple than Community based tourism research during the year 2010-2020. However, in terms of total annual citation from Table 1, the numbers are close to each other in adventure (55), eco (60) and communitybased articles (75). Whilst, the number of citations in rural tourism (112) research is almost doubled meaning that academic recognition of the term rural tourism research in the field of local community-based tourism studies are emphasized.

\subsection{The country production performance}

It's likely that the total number of publications from one country would correlate with overall attention in this area. These three graphs display the most active nations, where only the ethnicity of the first author is taken into consideration. The largest percentages of adventure tourism publications are represented by the UK (60\%), South Africa (40\%) which the USA (35), and are considered the most productive countries for the field as a whole [32].

Bequeath the Western Cape, South Africa's phenomenal growth of tourism is due to its natural beauty, the wildlife and vegetation found there, and the province's lush, forested interior [33]. In Figure 3, South Africa was ranked fifth in the top five countries of eco-tourism that derived from community tourism [3, 9, 34]. The first country in the world to introduce eco-tourism as a national tourism strategy was South Africa in 1996. The responsible tourism conference was conducted as ancillary to the World Summit on Global Action, also known as the Johannesburg Summit, in 2002. This conference 
established guidelines for responsible tourism and released the Cape Town's 2002 Tourism Strategy Declaration in order to combat the problem [35]. Both levels of government, multilateral organisations, as well as destinations and enterprises, and all communities and tourists are encouraged to take charge of making sustainable tourism a reality, so that local residents can be assured of a better quality of life. The only country to have a "fair trade" mark for its tourism products and services is South Africa [22].

\section{Country Production of Community-Based} Tourism Articles 2010-2020

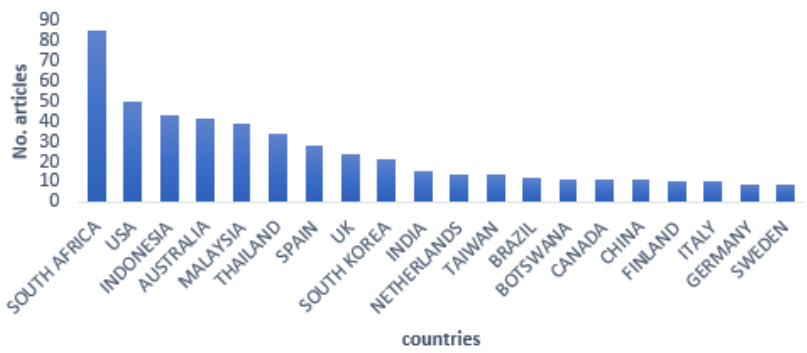

Figure 3. Country production as first author basis in community-based tourism articles publications 2010-2020

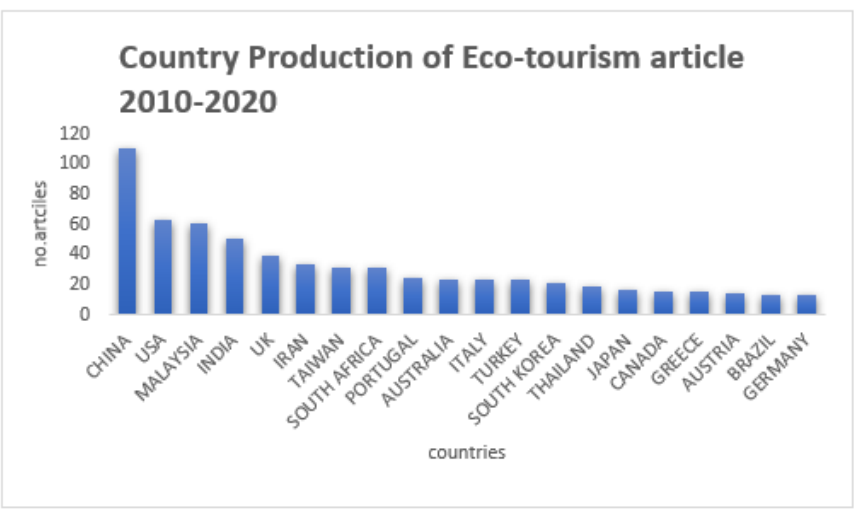

Figure 4. Country production as first author basis in Ecotourism articles publications 2010-2020

\section{Country Production of Rural Tourism Articles \\ 2010-2020}

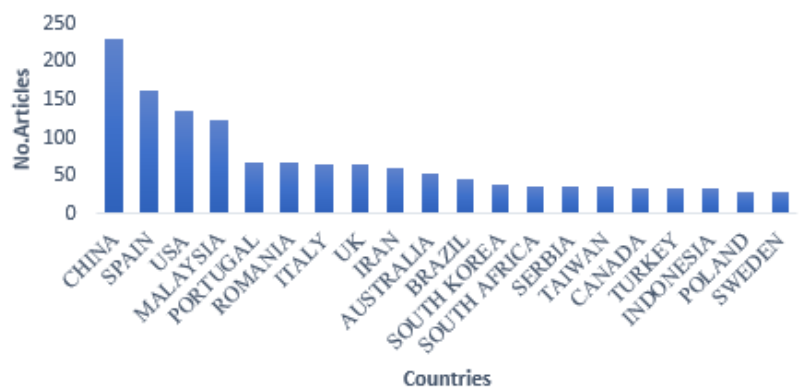

Figure 5. Country production as first author basis in Rural tourism articles publications 2010-2020

China is the most successful country in terms of eco-tourism Figure 4 and Rural Tourism Figure 5 research in the period
2010-2020 with 120 and 250 articles respectively. Although USA and Spain are the second and third most active countries with 60 in research on ecotourism and 150 in research on rural tourism, respectively. It's no wonder that of all these four-local community-based tourism surveys, the USA is one of the most successful countries. In the US, the eco-tourism industry is primarily owned and operated by local private companies. Nonetheless, there are several major land and water management agencies in the US government that fund and encourage local tourism focused on Eco, Rural and Adventure $[36,37]$.

China scored highest in both eco-tourism and rural tourism. As the Chinese economy grows, so does the Chinese tourism industry. China has a large population, and serious environmental issues stemming from a high public awareness. Furthermore, one of China's most influential research funding agencies, the Natural Science Foundation of China (NSFC) developed a new theme for tourism as part of its science division and attracted national attention [35, 38].

It looks as if there are roughly 5 Asian and 4 European countries participating in the world's top 15 most popular nations in adventure tourism, eco-tourism, and eco-tourism projects.

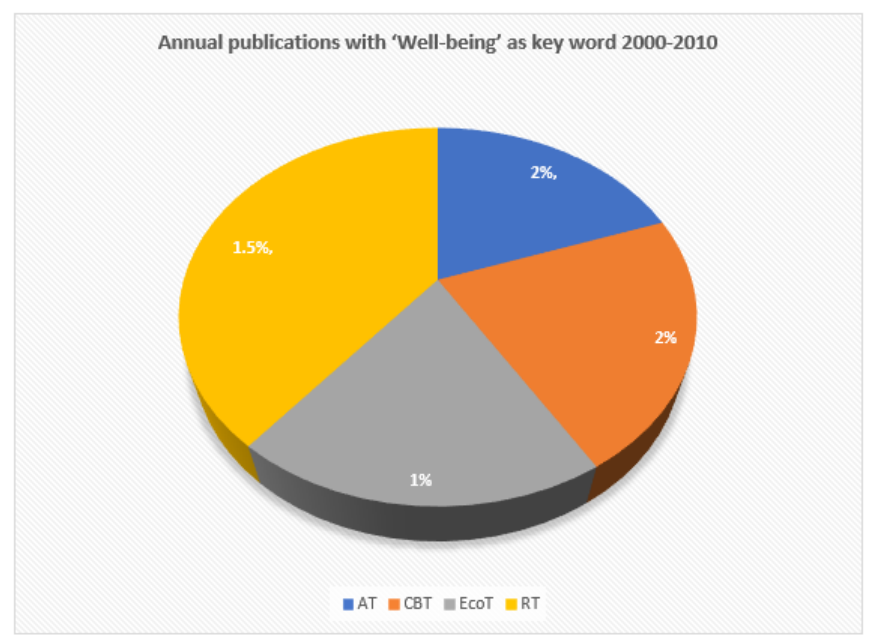

Figure 6. Annual publications with 'Well-being' as key word 2000-2010

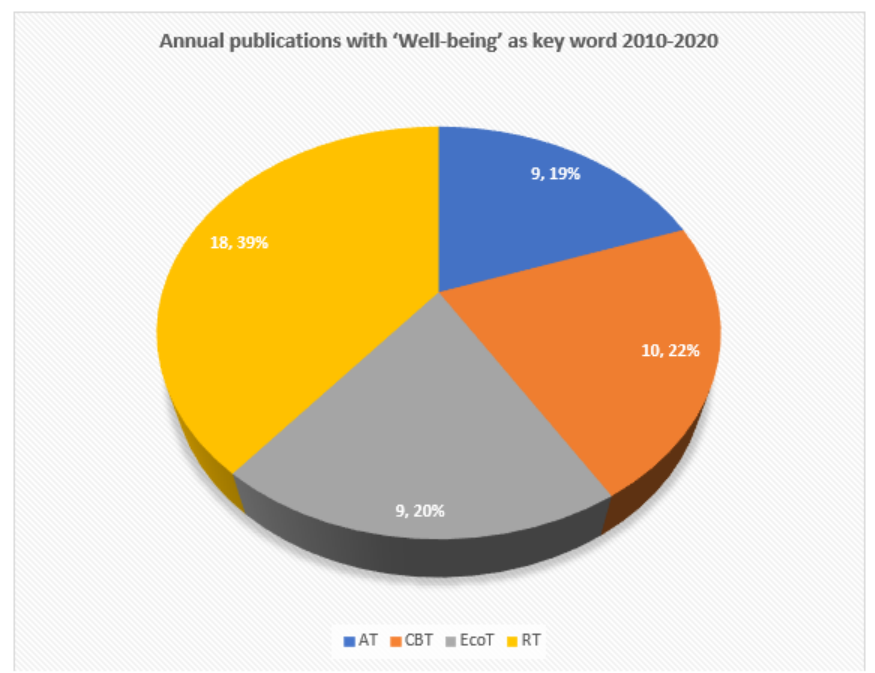

Figure 7. Annual publications with 'Well-being' as key word 2010-2020 
One of our key objectives of this research is to find out the growing global trend that has considerable potential as a transformative service is tourism implies Well-being and Tourism research. Thus, we are interested to investigate global trend on local tourism and well-being research before and after the year 2010 when transformative services research (TSR) was first conceptualized by Anderson (2010), as an investigation of the relationship between service and wellbeing and subsequently in the field of tourism service study (ref). After carefully observation, this research has found very few articles published before 2010 using well-being and Adventure Tourism (AT), Community-Based tourism (CBT), Eco-tourism (EcoT) and Rural Tourism (RT) keywords in Figure 6. Whilst there is a significant increase in the global research on using Well-being and all these keywords after the year 2010 in Figure 7 when the transformative service research and well-being introduced and applying the concept in various service research such as tourism. This is an interesting and significant outcome of our study to establish the increasing global trend on well-being and local tourism research in the form of adventure, eco-tourism, community-based and rural

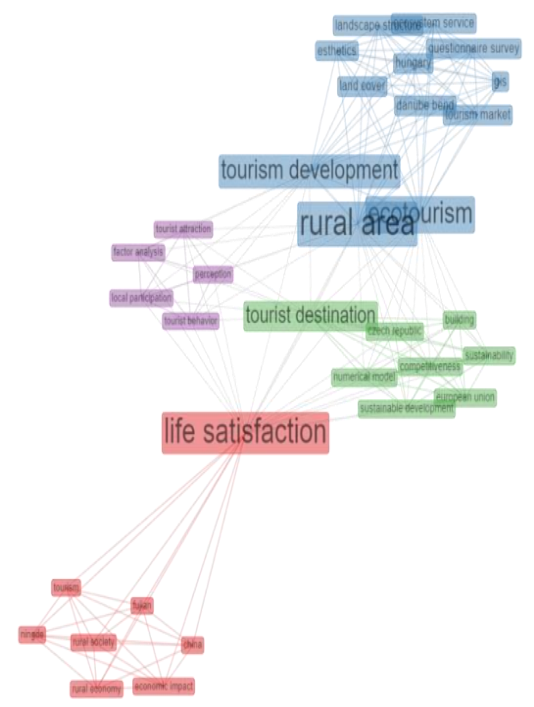

Figure 8. Keyword network analysis on rural tourism related articles during 2010-2020

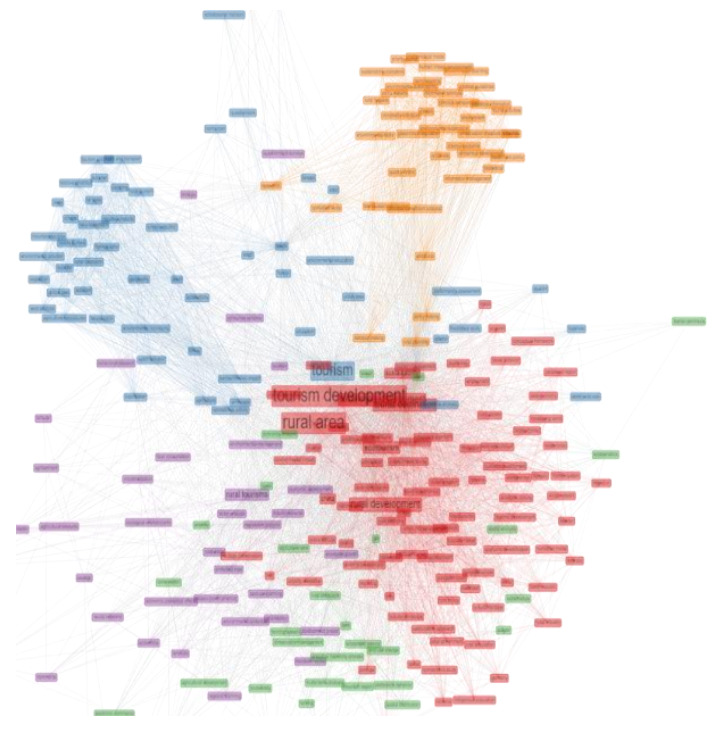

Figure 10. Keyword network analysis on community-based tourism during 2010-2020 tourism to illustrate the enhancement of host community wellbeing and development strategy of local tourism in the respective countries.

\section{THEMATIC MAP ON KEYWORDS NETWORK ANALYSIS}

The most frequently used words used in top-five journals during the year 2010-2020 were presented in Figures 8-11 using Rural, Eco, Community and Adventure tourism, respectively. Connections between nodes get thicker as the number of connections increase. Thickness and size of the circles around the nodes mean that centrality degrees of the nodes are high. Coloring in the network is determined in accordance with the time table above according to the years in which words are used $[9,20,22]$. As a result of the analysis, 35 words were detected and the most frequently-used top twenty words with the highest centrality degree were presented in the below figures respectively.

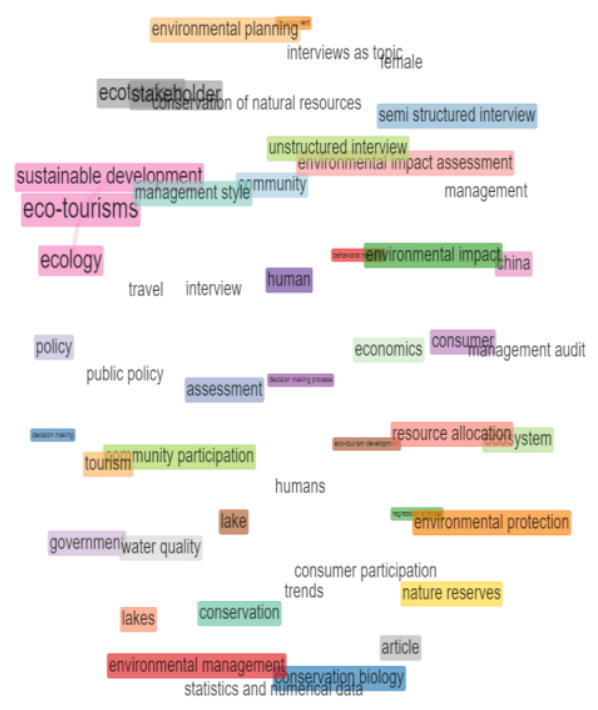

Figure 9. Keyword network analysis on eco-tourism related articles during 2010-2020

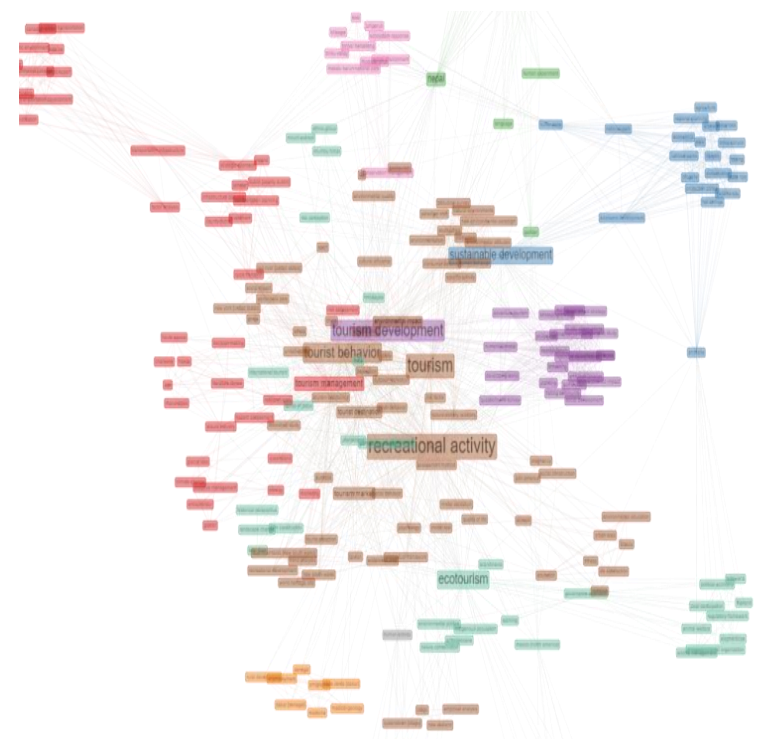

Figure 11. Keyword network analysis on adventure tourism related article 2010-2020 
According to the data presented in Figures 8-11, it is seen that the most frequently used words in top-five journals are "tourism" $(\mathrm{n}=25)$, "tourism development" $(\mathrm{n}=75)$ and "rural area" $(\mathrm{n}=31)$ and the concepts that have the highest betweenness degree are "behavior" $(0.15)$, "management" $(0.17)$ and "satisfaction" (0.20). Words with high centrality degrees represent the top topics that studies are concentrated on during the year 2010-2020. This thematic Map has also suggested the growing link between rural tourism and community satisfaction research in recent years. This also indicate that, researchers are interested to work on community satisfaction, eco-tourism, and rural tourism as their case studies particularly in rural areas. This is also an interesting finding to illustrate the research trend shifted towards well- being and local tourism research especially after the year 2010 .

\section{CRITICAL REVIEW OF MAJOR RESEARCH METHODS IN THE FIELD OF RT, AT, EcoT and CBT}

In this section, we present a selection of papers that have used different methodologies in their research in rural tourism and its variants. We also summarize the major findings and limitations of the research. More importantly, for each of these studies we suggest opportunities and directions of future research. All these studies included in Table 2 below are selected from Scopus database published after 2000 until 2020.

Table 2. Major research methods in the field of RT, AT, EcoT and CBT

\begin{tabular}{|c|c|c|c|c|}
\hline Author & Research method & Sample size & Findings & $\begin{array}{c}\text { Limitations/ future research } \\
\text { opportunity }\end{array}$ \\
\hline $\begin{array}{l}\text { Moscardo } \\
\text { (2014) [9] }\end{array}$ & Literature review & & $\begin{array}{l}\text { Local outsider destination was not } \\
\text { a useful way to classify actor in } \\
\text { tourism development and } \\
\text { community entrepreneurs could } \\
\text { act most powerfully in favor of } \\
\text { tourism and destination } \\
\text { community }\end{array}$ & $\begin{array}{l}\text { Fewer research on community } \\
\text { development officers and their role on } \\
\text { tourism development. Future studies } \\
\text { should disclose relationship between } \\
\text { entrepreneur and destination community } \\
\text { in more details. }\end{array}$ \\
\hline $\begin{array}{l}\text { Adeyinka- } \\
\text { Ojo et. al. } \\
(2014) \text { [39] }\end{array}$ & Literature review & & $\begin{array}{l}\text { Establish the necessity of having } \\
\text { local management and destination } \\
\text { marketing organization (DMMO) } \\
\text { in rural tourism destination. This } \\
\text { paper identified rules of DMMOs } \\
\text { and developed a framework for } \\
\text { DMMOs. }\end{array}$ & $\begin{array}{l}\text { Relies mostly on secondary research and } \\
\text { reviews of literature on rural tourism. } \\
\text { Future studies should attempt to conduct } \\
\text { empirical research among rural } \\
\text { destination stakeholders, to identify the } \\
\text { challenges and complexities. }\end{array}$ \\
\hline $\begin{array}{l}\text { Nawijn \& } \\
\quad \text { Mitas } \\
\text { (2012) [40] }\end{array}$ & Case study & 373(interview method) & $\begin{array}{l}\text { Residents were quite happy and } \\
\text { tourism are associated with } \\
\text { cognitive component of subjective } \\
\text { wellbeing }\end{array}$ & $\begin{array}{l}\text { Firstly, this study only addressed on } \\
\text { socio cultural and economic and overall } \\
\text { QOL impacts. Future study should } \\
\text { examine perceived environmental } \\
\text { impacts. } \\
\text { Secondly, sampling method used in this } \\
\text { paper is not ideal, future studies could } \\
\text { use more representative type of } \\
\text { sampling. } \\
\text { Thirdly, as this study is cross sectional } \\
\text { study it is not able to distinguish cause- } \\
\text { effect relationship, residents' attitudes } \\
\text { and SWB. }\end{array}$ \\
\hline $\begin{array}{l}\text { Kim et al. } \\
(2012)[41]\end{array}$ & $\begin{array}{l}\text { Questionnaire (test a } \\
\text { theoretical model) }\end{array}$ & $\begin{array}{l}321 \text { responses were } \\
\text { received out of } 2400\end{array}$ & $\begin{array}{l}\text { Results were almost supportive of } \\
\text { the theoretical model of rural } \\
\text { tourism generates well-being in } \\
\text { the local community. }\end{array}$ & $\begin{array}{l}\text { Sample population consisted of residents } \\
\text { from pre-selected cities based on four } \\
\text { secondary indicators. In literature } \\
\text { selection method is different (Butler, } \\
1980 \text { and Haywood, 1986). If the areas } \\
\text { had been selected by using the number of } \\
\text { visitors to a community, the results } \\
\text { might have been different. } \\
\text { Secondly, future studies should dynamic } \\
\text { interaction among impact dimension and } \\
\text { particular life domain. }\end{array}$ \\
\hline $\begin{array}{l}\text { Stem et al. } \\
(2012)[42]\end{array}$ & $\begin{array}{lr}\text { Case study (Costa Rica) } \\
\text { Mixed-methods } \\
\text { approach. } \\
\text { qualitative } r \text { methods } \\
\text { included focus-group } \\
\text { discussions, } r \text { open- } \\
\text { ended r informal } \\
\text { interviews, and } & \text { direct } \\
\text { observation. }\end{array}$ & $\begin{array}{l}\text { Total numbers of surveys } \\
\text { are } 214 \text { and qualitative } \\
\text { interviewees are } 120 .\end{array}$ & $\begin{array}{l}\text { Where ecotourism offers a viable } \\
\text { economic alternative, tourism } \\
\text { opportunities have induced people } \\
\text { to abandon cultivated land, } \\
\text { allowing forests to regenerate. } \\
\text { Employment in tourism, however, } \\
\text { reveals minimal influence on } \\
\text { conservation perspectives. }\end{array}$ & $\begin{array}{l}\text { To better understand ecotourism's role in } \\
\text { conservation, there is a need for similar } \\
\text { studies in other areas, as well as more } \\
\text { systematic research on the benefits and } \\
\text { impacts of ecotourism. Such studies } \\
\text { should follow the same communities } \\
\text { over several years to collect baseline and } \\
\text { subsequent monitoring data for } \\
\text { comparison over time with exposure to } \\
\text { tourism }\end{array}$ \\
\hline
\end{tabular}




\begin{tabular}{|c|c|c|c|c|}
\hline $\begin{array}{l}\text { Lee and Jan } \\
(2019) \text { [43] }\end{array}$ & Questionnaire & 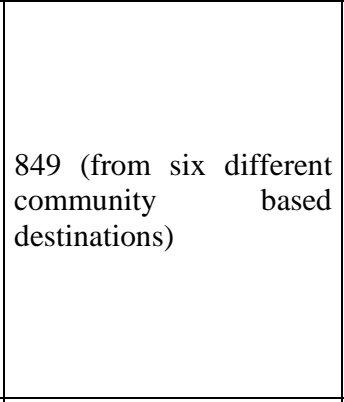 & $\begin{array}{l}\text { The economic, socio-cultural, and } \\
\text { environmental sustainability } \\
\text { varied significantly in various } \\
\text { stages of community based } \\
\text { tourism. }\end{array}$ & $\begin{array}{l}\text { Firstly, some factors are overlooked in } \\
\text { this study, such as perspective of tourists } \\
\text { and effect on environments. } \\
\text { Secondly, some other studies argued } \\
\text { about "political issues" as the basis of } \\
\text { residents perceptions, which is also } \\
\text { overlooked in this study. } \\
\text { Finally, the questionnaire did not } \\
\text { appropriately reflect residents' } \\
\text { psychological and emotional attitudes } \\
\text { towards tourism development. }\end{array}$ \\
\hline $\begin{array}{l}\text { Hunt et al. } \\
\text { (2014) [44] }\end{array}$ & $\begin{array}{c}\text { Case study (Osa } \\
\text { Peninsula, Costa-Rica) }\end{array}$ & $\begin{array}{l}128 \quad \text { semi-structured } \\
\text { interviewees. }\end{array}$ & $\begin{array}{l}\text { Local resident's perception is } \\
\text { positive towards rural tourism in } \\
\text { improving quality of life and } \\
\text { environmental conservation. }\end{array}$ & $\begin{array}{l}\text { Further research is needed to anticipate } \\
\text { the effect of several pending large-scale } \\
\text { development in Osa region. }\end{array}$ \\
\hline $\begin{array}{l}\text { Moscardo } \\
\text { et al. }(2013) \\
\quad[45]\end{array}$ & $\begin{array}{l}\text { Interview (qualitative } \\
\text { approach) }\end{array}$ & $\begin{array}{l}\text { Semi-structured } \\
\text { interviews with } 25 \\
\text { persons from three } \\
\text { regional communities in } \\
\text { tropical Australia. }\end{array}$ & $\begin{array}{l}\text { The study found that patterns of } \\
\text { impacts could be connected to } \\
\text { these distinct types of tourists. } \\
\text { Four key themes were identified } \\
\text { and described. These themes are } \\
\text { income generation, local } \\
\text { economic growth, local } \\
\text { community development and } \\
\text { indigenous culture development. }\end{array}$ & $\begin{array}{l}\text { The study was not specifically aimed nor } \\
\text { designed to examine mobility. Future } \\
\text { studies could provide a better } \\
\text { understanding of tourism sustainability } \\
\text { with guidance from both NMP and } \\
\text { frameworks and concept from the } \\
\text { community wellbeing literature. }\end{array}$ \\
\hline $\begin{array}{l}\text { Trejos \& } \\
\text { Chiang } \\
(2009)[46]\end{array}$ & Case study (Costa Rica) & $\begin{array}{l}\text { Face-to-face, and semi- } \\
\text { structured interviews } \\
\text { with } 8 \text { CBT support } \\
\text { organizations,26 } \\
\text { grassroots organizations, } \\
\text { and 12 Chira villagers. } \\
\end{array}$ & $\begin{array}{l}\text { CBT may only have small-scale } \\
\text { positive impacts on the local } \\
\text { economy. }\end{array}$ & $\begin{array}{l}\text { Case studies may be generalized to } \\
\text { theoretical propositions but not to } \\
\text { populations or universes (Yin, 2003), so } \\
\text { these findings are not intended as a } \\
\text { representative sampling of CBT } \\
\text { businesses, }\end{array}$ \\
\hline
\end{tabular}

\section{RESEARCH KEY POINTS AND CONTRIBUTION TO THE LITERATURE: RESEARCH DIRECTIONS}

Several studies which focused on the bibliometric analysis have dealt with the issue of eco-tourism. In one study researchers focused on key eco-tour concepts, such as that of eco-tourism [47]. This is just a small piece of the pie in terms of related Rural, Adventure, and Community-based Tourism research, and other studies will need to be performed in order to gain a comprehensive view of their state. In another study [48] researchers performed a literature review which also includes vacation learning. However, this study will only cover one dimension of tourism, namely nature-based tourism, is concerned. Additionally, they are concentrating on elements of nature-based tourism that don't deal with either themes or other kinds of tourism and, but which do make it possible to classify the latter. Still, though their article is more general, advocates a tourism-sustainability initiative [49]. Up-to-todate information is provided in relation to both eco-tourism and the practice of small-based tourism over the next decade is part of our research's emphasis. we use bibliometric and network analysis as well as country-specific studies to look for more complicated trends, along with literary research, to better understand the patterns, and academic collaboration for places that can make significant contributions to research. such a mixture is capable of gathering important search words, of analysis, significant quotations from or interactions, and one possible routes as well as a preliminary goals.

Study results from the use of this Rural, Eco, Adventure, and Community Tourism bibliometrics showed substantial growth among both developed and developing countries. with greater concern for natural habitats, future research emphasis is likely to focus on community regulations and policy. This project will inspire, as well as help, politicians, promoters of rural tourism, and contribute to participants in the effort to ensure a participation in improving the welfare of the local ecosystems through jobs. On top of that, facilitating community engagement in order to foster and protect development is critical. Further work will be undertaken to provide analytical evidence on the outcomes of different polices applied both at a local and an international level, with the intention of ensuring the consistency and proper use of resources. Formal studies are useful in examining the various possibilities for vacationing in rural, community-based, and eco-tourism environments so that appropriate local policies can be put in place for each of them. Possible conclusion: Finally, some international comparative studies should be conducted to allow people from other nations to learn and compare rural tourism methods while rural tourism practitioners from all nations can exchange information. Thus, rural tourism could serve as a potential source of community well-being. This is just the beginning of this whole new line of thought that moves into narrative and bibliometric investigation.

\section{CONCLUSION AND CONTRIBUTION}

Rural tourism will support economic growth as well as conserving for the rural area's population. More holistic or efficient eco-tourism can include initiatives from governments, tourists, suppliers, and tourism managers. but recent years have seen considerable changes in rural tourism activities as a result of limited knowledge of its characteristics. Careful planning and management is crucial to avoid unintended impacts, as well as to preserve a socially, ecologically, and economically harmonious environment. Academic progress has been made because of rapid growth in tourism and the subsequent environmental problems. In order to elucidate the historical trends and embody the main attributes of this 
research identified and scheduled on this region, this area of rural tourism, it carried out bibliometric analysis for the period between 2000 and 2020. When it became possible to perform transformation experiments in 2010, total publications increased and eventually rolled over to rural tourism studies. There have been studies concerning agricultural, adventure tourism, community-based, and ecotourismatics in the area beginning of the new since 2010. The methodology, exploration, and aesthetics of the research output enable us to better appreciate the countries that are now focused on promoting rural tourism, which countries have grown and what kind of citations these were, and which ideas have proliferated. China, the United Kingdom, and the United States are some of the leaders in this part of the world. these countries are often partnered with universities The most widely cited paper focuses on growth of rural tourism with regard to other countries as well. most important article deals with ecotourism in the tourism, while the third discussed ecotourism in population development. Eco-tourism, sustainable growth, tourism, protected, and also known as green tourism are the most commonly used words. Finally, long-term goals and guidelines are presented as well as methods for further study are discussed. Although theme and content analysis have briefly discussed their respective weaknesses, future research have focused on the field of studies. The aim of this literature review is to provide a detailed perspective on the issues facing tourism in general. Some of the most significant findings include valuable information about rural tourism, and useful ideas which can aid in figuring out the best approach to study topics and methods.

\section{LIMITATIONS AND FUTURE RESEARCH}

Also, publications and citations outside the SCOPUS were omitted in this review, which may be influential may be more common. Additionally, future studies can use other sources, such as Web of Science, Google Scholar, ProQuest, and Google Academic Search for better results.

\section{REFERENCES}

[1] Barbieri, C., Sotomayor, S., Gil Arroyo, C. (2020). Sustainable tourism practices in indigenous communities: The case of the Peruvian Andes. Tourism Planning and Development, 17(2): $207-224$ https://doi.org/10.1080/21568316.2019.1597760

[2] Cañero Morales, P., López-Guzmán Guzmán, T., OrgazAgüera, F., Moral Cuadra, S. (2017). Sustainability in rural communities: Community-based tourism as a development tool. Espacios, 38(41).

[3] Wei, L.L., Johari, S., Bidin, S., Wei, T.P.Y.L.L. (2020). Local community participation in sustainable ecotourism development at Bagan Sungai Burung, Perak. Test Engineering and Management, 82(1-2): 1062-1077.

[4] Bernard, H.R., Harvey R., Ryan, G.W., Wutich, A. (2016). Analyzing Qualitative Data: Systematic Approaches. SAGE.

[5] Smith, M.K., Diekmann, A. (2017). Tourism and wellbeing. Annals of Tourism Research, 66: 1-13. https://doi.org/10.1016/j.annals.2017.05.006

[6] Cini, F., Kruger, S., Ellis, S. (2013). A model of intrinsic and extrinsic motivations on subjective well-being: The experience of overnight visitors to a national park. Applied Research Quality of Life, 8: 45-61 http://dx.doi.org/10.1007/s11482-012-9173-y

[7] De Bloom, J., Kompier, M.A., Geurts, S.A., Weerth, D.C., Taris, T., Sonnentag, S. (2009). Do we recover from vacation? Meta-analysis of vacation effects on health and well-being. Journal of Occupational Health, 51(1): 13-25. https://doi.org/10.1539/joh.k8004

[8] Dolnicar, S., Yanamandram, V., Cliff, K. (2012). The contribution of vacations to quality of life. Annals of Toursim Research, 39: 59-83. https://doi.org/10.1016/j.annals.2011.04.015

[9] Moscardo, G. (2014). Tourism and community leadership in rural regions: Linking mobility, entrepreneurship, tourism development and community well-being. Tourism Planning and Development, 11(3): 354-370.

https://doi.org/10.1080/21568316.2014.890129

[10] Anderson, L. (2010). "Improving Well-Being through Transformative Service" in "Moving Forward and Making a Difference: Research Priorities for the Science of Service' by Amy L. Ostrom, Mary Jo Bitner, Stephen W. Brown, Kevin A. Burkhard, Michael Goul, Vicki Smith-Daniels, HalukDemirkan, and Elliott Rabinovich, Journal of Service Research, 13(1): 4-36. https://doi.org/10.1177\%2F1094670509357611

[11] Anderson, L., Ostrom, A.L., Corus, C., Fisk, R.P., Gallan, A.S., Giraldo, M., Mende, M., Mulder, M., Rayburn, S. W., Rosenbaum, M. S., Shirahada, K., and Williams, J.D. (2013). Transformative service research: An agenda for the future. Journal of Business Research, 66: 1203-1210. https://doi.org/10.1016/j.jbusres.2012.08.013

[12] Rosenbaum, M.S., Corus, C., Ostrom, A.L., Anderson, L., Fisk, R., Gallan, A., Giraldo, M., Mende, M., Mulder, M., Rayburn, S.W., Shirahada, K., Williams, J.D. (2011). Conceptualisation and aspirations of transformative service research. Journal of Research for Consumers, 19: 1-6. https://ssrn.com/abstract=2643219

[13] Ostrom, A.L., Parasuraman, A., Bowen, D.E., Patrício, L., Voss, C.A. (2015). Service research priorities in a rapidly changing context. Journal of Service Research, $18(2)$ :

127-159. https://doi.org/10.1177/1094670515576315

[14] Boukas, N. (2019). Rural tourism and residents' wellbeing in Cyprus: Towards a conceptualised framework of the appreciation of rural tourism for islands' sustainable development and competitiveness. International Journal of Tourism Anthropology, 7(1): 60-86. https://doi.org/10.1177/1094670509357611

[15] Anderson, L., Ostrom, A.L. (2015). Transformative service research: Advancing our knowledge about service and well-being. Journal of Service Research, 18(3): 243-249. https://doi.org/10.1177/1094670515591316

[16] Black, H.G., Gallan, A.S. (2015). Transformative service networks: Cocreated value as well-being. The Service Industries Journal, 35(15-16): 826-845. https://doi.org/10.1080/02642069.2015.1090978

[17] Lugosi, P., Robinson, R.N.S., Golubovskaya, M., Foley, L. (2016). The hospitality consumption experiences of parents and carers with children: A qualitative study of foodservice settings. International Journal of Hospitality Management, 
https://doi.org/10.1016/j.ijhm.2016.01.012

[18] Galeone, A., Sebastiani, R. (2017). Transformative service research in the hospitality industry: The case of the "Albergo Diffuso". 20th Excellence in Services, University of Verona, International Conference Verona (Italy) Conference Proceedings.

[19] MacDonald, R., Jolliffe, L. (2003). Cultural rural tourism: Evidence from Canada. Annals of Tourism Research, 30(2): 307-322. https://doi.org/10.1016/S01607383(02)00061-0

[20] Da Silva Lopes, H., Remoaldo, P., Ribeiro, V. (2019). Residents' perceptions of tourism activity in a rural North-Eastern Portuguese community: A cluster analysis. Bulletin of Geography. Socio-Economic Series, 46(46): 119-135. https://doi.org/10.2478/bog-2019-0038

[21] Ryglová, K., Rašovská, I., Šácha, J. (2017). Rural tourism - evaluating the quality of destination. European Countryside, 9(4): 769-788. https://doi.org/10.1515/euco-2017-0043

[22] Shasha, Z.T., Geng, Y., Sun, H., Musakwa, W., Sun, L. (2020). Past, current, and future perspectives on ecotourism: A bibliometric review between 2001 and 2018. Environmental Science and Pollution Research, 27: 23514-23528. https://doi.org/10.1007/s11356-02008584-9

[23] Güzeller, C.O., Celiker, N.M. (2018). Bibliometric Analysis of Tourism Research for the Period 2007-2016. Advances in Hospitality and Tourism Research (AHTR), 6(11): 1-22. https://doi.org/10.30519/ahtr.446248

[24] Bellis, D.N. (2009) Bibliometric and citation Analysis: from the Science Citation Index to Cybermetrics. Scarecrow Press, Maryland.

[25] Hou, Q., Mao, G.Z., Zhao, L., Du, H.B., Zuo, J. (2015). Mapping the scientific research on life cycle assessment: a bibliometric analysis. Int J Life Cycle Assess, 20: 541555. https://doi.org/10.1007/s11367-015-0846-2

[26] Persson, O., Glanzel, W., Danell, R. (2004). Inflationary bibliometric values: The role of scientific collaboration and the need for relative indicators in evaluative studies. Scientometrics, $60(3)$ : 421-432. https://doi.org/10.1023/B:SCIE.0000034384.35498.7d

[27] Fu, H.Z., Ho, Y.S., Sui, Y.M., Li, Z.S. (2010). A bibliometric analysis of solid waste research during the period 1993-2008. Waste Manag., 30: 2410-2417. https://doi.org/10.1016/j.wasman.2010.06.008

[28] Liu, X., Zhang, L., Hong, S. (2011). Global biodiversity research during 1900-2009: A bibliometric analysis. Biodivers Conserv, 20(4): 807-826. https://doi.org/10.1007/s10531-010-9981-z

[29] Van Raan, A.F.J. (2005). For your citations only? Hot topics in bibliometric analysis. MeasInterdisc Res $\begin{array}{llr}\text { Perspect, } & 3(1) \text { : 50-62. }\end{array}$ https://doi.org/10.1207/s15366359mea0301_7

[30] Vieira, E., Gomes, J. (2009). A comparison of Scopus and Web of Science for a typical university. Scientometrics, $81(2)$ : 587-600 https://doi.org/10.1007/s11192-009-2178-0

[31] Burnham, J. (2006). Scopus database: A review. Biomedical Digital Libraries 3(8): 1-8Buryat State Agricultural Academy named after V. R. Philippov (BSAA) (Bearb.) (Ed.). (2012). Eco-tour and Tourism in Rural Areas. Selbstverl. RSAU-MTAA. https://doi.org/10.1186/1742-5581-3-1

[32] Gross, S., Sand, M. (2020). Adventure tourism: A perspective paper. Tourism Review, 75(1): 153-157. https://doi.org/10.1108/TR-06-2019-0211

[33] Lindsey, P., Alexander, R., Mills, M., Woodroffe, R., Romañach, S. (2007). Wildlife viewing preferences of visitors to protected areas in South Africa: Implications for the role of ecotourism in conservation. J Ecotour, 6: 19-33. https://doi.org/10.2167/joe133.0

[34] Hussin, R., Yasir, S.M., Kunjuraman, V. (2015). Potential of seaweed cultivation as a community-based rural tourism product: A stakeholders' perspectives. Advances in Environmental Biology, 9(5): 154-156.

[35] Bentley, T.A., Page, S.J. (2001). Scoping the extent of adventure tourism accidents. Annals of Tourism Research, 28(3): 705-726. https://doi.org/10.1016/S0160-7383(00)00058-X

[36] Huy, H.P., Khin, A.A. (2016). Eco-tourism development of Phu Quoc Island under resource-based view approach. International Journal of Economics and Financial Issues, 6(6Special Issue): 10-13.

[37] Roces-Díaz, J.V., Burkhard, B., Kruse, M., Müller, F., Díaz-Varela, E.R., Álvarez-Álvarez, P. (2017). Use of ecosystem information derived from forest thematic maps for spatial analysis of ecosystem services in northwestern Spain. Landscape and Ecological Engineering, 13(1): 45-57. https://doi.org/10.1007/s11355-016-0298-2

[38] Scaramuzzi, S., Belletti, G., Biagioni, P. (2020). Integrated Supply Chain Projects and multifunctional local development: The creation of a Perfume Valley in Tuscany. Agricultural and Food Economics, 8(1). https://doi.org/10.1186/s40100-019-0150-8

[39] Adeyinka-Ojo, S.F., Khoo-Lattimore, C., Nair, V. (2014). A framework for rural tourism destination management and marketing organisations. Procedia - Social and Behavioral Sciences, 144: 151-163. https://doi.org/10.1016/j.sbspro.2014.07.284

[40] Nawijn, J., Mitas, O. (2012). Resident attitudes to tourism and their effect on subjective well-being: The case of Palma de Mallorca. Journal of Travel Research, 51(5):

531-541. https://doi.org/10.1177/0047287511426482

[41] Kim, K., Uysal, M., Sirgy, M.J. (2013). How does tourism in a community impact the quality of life of community residents? Tourism Management, 36: 527540. https://doi.org/10.1016/j.tourman.2012.09.005

[42] Stem, C.J., Lassoie, J.P., Lee, D.R., Deshler, D.D., Schelhas, J.W. (2003). 'Community participation in ecotourism benefits: The link to conservation practices and perspectives. Society \& Natural Resources, 16(5): 387-413. https://doi.org/10.1080/08941920309177

[43] Lee, T.H., Jan, F.H. (2019). Can Community-based tourism contribute to sustainable development? Evidence from Residents' perceptions of the sustainability. Tourism Management, 70: 368-380 https://doi.org/10.1016/j.tourman.2018.09.003

[44] Hunt, C.A., Durham, W.H., Driscoll, L., Honey, M. (2015). Can ecotourism deliver real economic, social, and environmental benefits? A study of the Osa Peninsula, Costa Rica. Journal of Sustainable Tourism, 23(3): 339-357. https://doi.org/10.1080/09669582.2014.965176

[45] Moscardo, G., Konovalov, E., Murphy, L., McGehee, N. (2013). Mobilities, community well-being and sustainable tourism. Journal of Sustainable Tourism, 
21(4):

https://doi.org/10.1080/09669582.2013.785556

[46] Trejos, B., Chiang, L.H.N. (2009). Local economic linkages to community-based tourism in rural costa Rica. Singapore Journal of Tropical Geography, 30(3): 373387. https://doi.org/10.1111/j.1467-9493.2009.00375.x

[47] Weaver, D.B., Lawton, L.J. (2007). Twenty years on: The state of contemporary ecotourism research. Tour Manag., 28:

1168-1179.
[48] Ardoin, N.M., Biedenweg, K., O’Connor, K. (2015). Evaluation in residential environmental education: an applied literature review of intermediary outcomes. Appl Environ Educ Commun., 14: 43-56. https://doi.org/10.1080/1533015X.2015.1013225

[49] Auala, L.S.N., van Zyl, S.R., Ferreira, I.W. (2019). Township tourism as an agent for the socio-economic well-being of residents. African Journal of Hospitality, Tourism and Leisure, 8(2). 